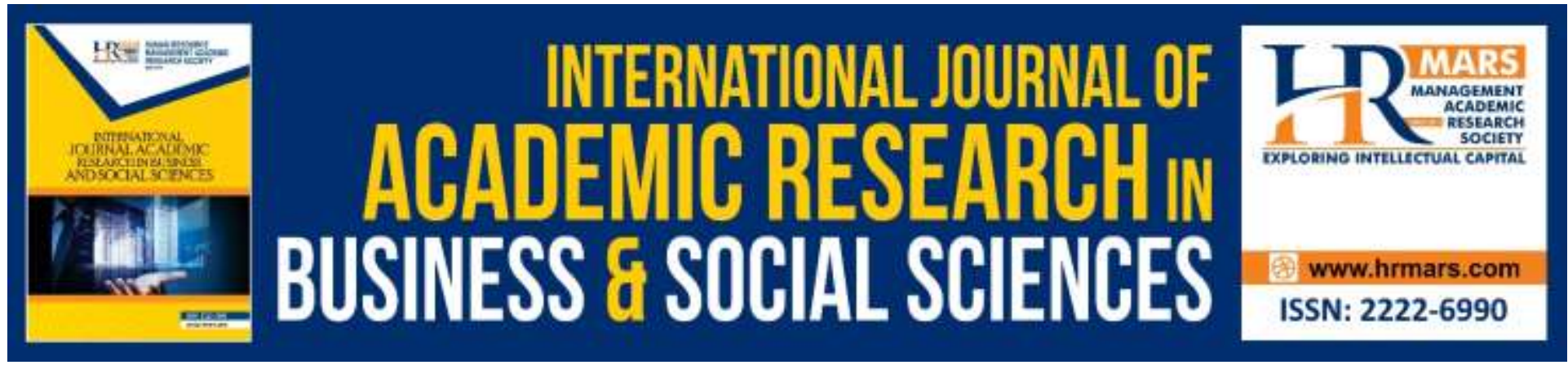

\title{
Macroeconomy and Company's Policy on Firm Value: An Interactive Effect on Manufacturing Companies Listed in Idx Period 2013-2017
}

Agustinus Miranda Wijaya, Tri Widyastuti, Agoestina Mappadang

To Link this Article: http://dx.doi.org/10.6007/IJARBSS/v9-i9/6404

DOI: $10.6007 /$ IJARBSS/v9-i9/6404

Received: 29 July 2019, Revised: 12 August 2019, Accepted: 30 August 2019

Published Online: 25 September 2019

In-Text Citation: (Wijaya, Widyastuti, \& Mappadang, 2019)

To Cite this Article: Wijaya, A. M., Widyastuti, T., \& Mappadang, A. (2019). Macroeconomy and Company's Policy on Firm Value: An Interactive Effect on Manufacturing Companies Listed in Idx Period 2013-2017. International Journal of Academic Research in Business and Social Sciences, 9(9), 1085-1099.

Copyright: (C) 2019 The Author(s)

Published by Human Resource Management Academic Research Society (www.hrmars.com)

This article is published under the Creative Commons Attribution (CC BY 4.0) license. Anyone may reproduce, distribute, translate and create derivative works of this article (for both commercial and non-commercial purposes), subject to full attribution to the original publication and authors. The full terms of this license may be seen at: http://creativecommons.org/licences/by/4.0/legalcode

Vol. 9, No. 9, 2019, Pg. 1085 - 1099

http://hrmars.com/index.php/pages/detail/IJARBSS

JOURNAL HOMEPAGE

Full Terms \& Conditions of access and use can be found at http://hrmars.com/index.php/pages/detail/publication-ethics 


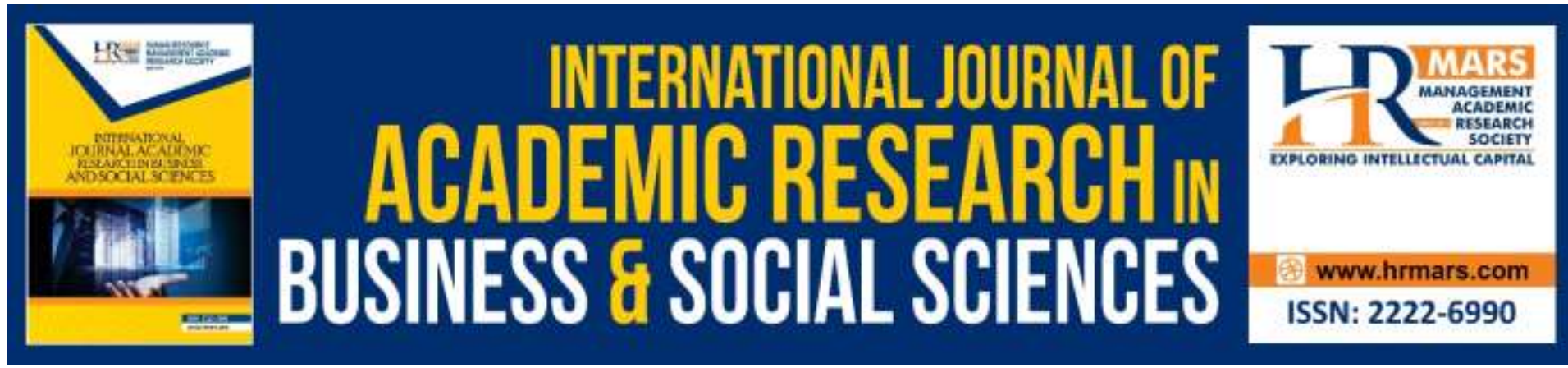

\title{
Macroeconomy and Company's Policy on Firm Value: An Interactive Effect on Manufacturing Companies Listed in Idx Period 2013-2017
}

\author{
${ }^{1}$ Agustinus Miranda Wijaya, ${ }^{2}$ Tri Widyastuti, ${ }^{3}$ Agoestina \\ Mappadang \\ ${ }^{1}$ Agustinus Miranda Wijaya, Department of Post Graduate, Program Doctoral \\ Universitas Pancasila JI. Borobudur no. 7 Jakarta Pusat, DKI Jakarta 10320, Indonesia \\ ${ }^{2}$ Tri widyastuti, Universitas Bhayangkara, Jl. Perjuangan no. 81, Kec Bekasi Utara, \\ Bekasi, Jawa Barat 17143 Indonesia, ${ }^{3}$ Agoestina Mappadang, Department of Accounting, \\ Economy, Universitas Budi Luhur, JI. Ciledug raya, RT 10/RW 2, Petukangan Utara, Kec. \\ Pesangrahan, Kota Jakarta Selatan, DKI Jakarta 12260, Indonesia
}

\begin{abstract}
The purpose of this study to answer some questions on the factors impact on firm value in Indonesia Stock Exchange. This study, in specific, aims to test the gradual effect of macroeconomy and policy of the company on firm value. The concept used in measuring the fundamental macroeconomic factors of interest rates and exchange rates is the concept of the sensitivity of the interest rate and exchange rate factors of each company. While the concept used to measure company policy is capital expenditure and to measure company value is Tobins'q. This study used the samples of the manufacture industries from period 2013-2017, which the stock actively traded in Indonesia Stock Exchange (BEI). The sampling was purposive, and the analytical technique was SEM-PLS. The research outcome that the interest rate has a significant positive effect on firm value; the exchange rate has a significant negative effect on firm value, and the capital expenditure has a significant negative effect on firm value.
\end{abstract}

Keywords: Macroeconomy, Interest Rate, Exchange Rate, Capital Expenditure, Tobins'q

\section{Introduction}

The company has a high-profit orientation so that the value of the company is very important because it is related to the development of company assets that can affect investor perceptions of the company. If the company's performance is getting better, it will obtain higher investor returns. Investors in the stock exchange will see the stock price as a representation of the value of the company which is not only determined by internal factors of the company but also determined by external factors of the company. Company external 
factors and company internal factors are fundamental factors that are often used as a basis for investors in the capital market when making investment decisions.

In addition to fundamental factors, some factors that are quite important and can affect stock prices, namely technical and psychological factors. These technical factors include the tendency of rising and falling stock prices, the value of stock trading transactions, and trading volume of shares. If the stock prices of companies listed on the capital market fluctuate from year to year, then it will certainly affect the interest of investors in investing. Changes in stock prices can not separate from the influence of market forces, namely the high and low demand and supply. If the volume of demand and supply increases, the share price will fluctuate. The higher trading volume shows that the stock is more attractive to investors and will lead to rising share prices (Jogiyanto Hartono, 2010).

The development of the manufacturing industry in a country as a parameter to see the development of the national industry in the country both in terms of product quality aspects and overall industry performance can see in Figure 1.1.

Picture 1.1

Stock Price Index Chart of Manufacture Industries Listed at Indonesia Stock Exchange for period 2012-2015.

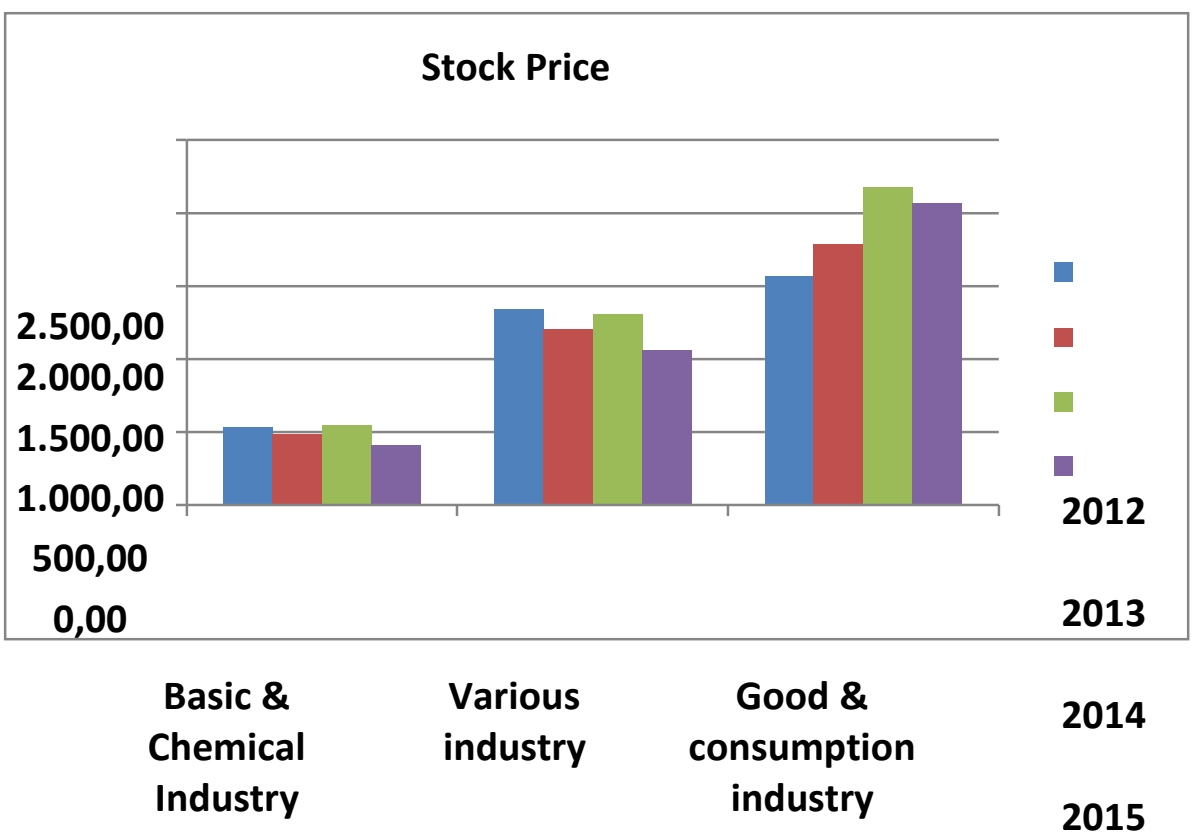

\section{Source: www.idx.co.id}

Figure 1.1 shows the magnitude of the stock price index of manufacturing companies listed on the Indonesia Stock Exchange in the 2012-2015 period fluctuated and it saw that the stock price based on the closing price has increased and decreased. Fundamentals factors generally influenced the stock prices in the capital market. Fundamental factors can be grouped into fundamental macro and fundamental micro factors. Macro fundamental factors come from outside the company, such as economic, environmental, political, legal, social, cultural, security, education, etc. The company can not control fundamental macro but very 
big influence if there is a change. Analysts and capital market players generally analyse macrofundamental factors because macroeconomic factors touch directly and are more measurable, namely through indicators of interest rates and exchange rates. Interest rate and exchange rate volatility has the potential to increase or decrease systematic risk or market risk because movements in interest rates and exchange rates are beyond the control of the company, and all companies will be affected.

In economic theory, movements in interest rates and exchange rates have the potential to increase or decrease investment in the real sector and affect the performance of the capital market. Investment in the capital market becomes riskier if the volatility of the movement is high. Each company, in general, will experience a different effect from the movement of interest rates and exchange rates. These variables of interest rates, exchange rates, and systematic risk can have the potential to increase or decrease the value of the company. Interest rates and exchange rates are two factors that receive considerable attention from business people in the capital market. These two macroeconomic indicators have the potential to increase and decrease firm value.

The company's fundamental factors, in this case, the company's policies also affect the company's stock price. Some of the policies taken are investment policies and profit distribution policies or dividend policies. The investment policy will be decided to add new equipment if there is a tendency for economic conditions to improve. One of the company's policies can be seen from the capital expenditure related to the policy in funding that must be supported by good asset management. Including the management of related resources because this capital expenditure policy is very supportive of success in the financing selection program. In the end, this policy has an impact on increasing the value of the company.

The business done by the company in allocating new capital expenditure will be able to see the results after a few years later because this involves long-term investment. It is in line with investment theory, which is intended to expand business opportunities and can only justified if the company's performance is getting better. The Investment decisions regarding the management of funds in a certain period, the investors have the hope to obtain income or profits from the funds invested during a certain period. Every decision taken by an investor when making a new investment needs to go through a careful analysis when reading uncertain market situations. Investment in the stock market is an investment that has a high risk, because the nature of the commodity is very sensitive to macroeconomic changes that occur, both domestically and abroad. It is also influenced by changes that occur in the industry and the company itself. Changes in the economy that cause an increase in interest rates and exchange rates will make investment activities decline. These conditions directly affect the behaviour of investors when making investment decisions in the capital market. It is a challenge and a tough task for managers to keep the company in existence through policies that can maintain or even increase the market price of the company's shares in the capital market so that the company's value increases.

Based on the research gap that was developed by researchers as well as the phenomenon of empirical economic conditions in Indonesia, and the phenomenon of manufacturing industry companies on the Indonesia Stock Exchange, the underlying problem of this research is the inconsistency of fundamental macroeconomic variables, such as interest rates and exchange rates and company policies in affect on company performance and company value. 


\section{Related Literature \\ Firm Value}

The company's value in this study proxied by the size of Tobin's $Q$, which is an element of calculation of Tobin's $Q$ is the market value of common stocks and financial liabilities. The value of the company is the value of all assets owned by the company consisting of the market value of its capital and the market value of debt. Researchers use Tobin's $Q$ measure as one of the assessment tools for measuring company value that has been widely used by other researchers such as AnasAl \& Laham, (2013) who conduct research on systematic risk, nonsystematic risk and total risk; (Riza umma Mustika, 2017) who conducted research on ownership structures and diversification strategies; (Villalonga, 2004) who examined leverage, capital expenditure and market risk (beta).

\section{Macroeconomy}

The basic concept that there is a relationship between fundamental macroeconomic factors and company value is that corporate value cannot be separated from macroeconomic conditions. (Parlapiano et al., 2017). This factor has the potential to influence company policy and company value. It means that every determination of company policy must pay attention to fundamental macroeconomic factors, such as interest rates and exchange rates in addition to inflation and economic growth. Interest rates and exchange rates are factors that get the attention of the investor in the capital market (Kasman, Vardar, \& Tunç, 2011). In economic theory, movements in interest rates and exchange rates have the potential to increase or decrease investment in the real sector and affect the performance of the capital market. Investment in the capital market becomes riskier if the volatility of the movement is high. Each company, in general, will experience a different effect from the movement of interest rates and exchange rates.

\section{Interest Rate}

The first indicator of macroeconomic factors from macroeconomic conditions is the interest rate. Interest rates often used as a measure of income earned by capital owners, and this interest rate is called savings or investment interest. Likewise, the interest rate used as a measure of capital costs that companies must incur to use funds from capital owners; this is called loan interest. Therefore, the interest rate is a price that is willing to be paid by people who need money, and this happens in the money market and capital market. Rising interest rates will encourage people to save, and lazy to invest in the real sector. An increase in interest rates will also be borne by investors, in the form of an increase in interest costs for the company (Hamrita \& Trifi, 2011). The public does not want to risk investing in high costs; as a result, investment become undeveloped. Many companies have difficulty maintaining their lives, and this causes the company's performance to decline. The decline in company performance can result in a decrease in share prices, with a decrease in share prices, meaning the value of the company also decreases.

The research on interest rate problems has been conducted by Sudjono, (2002), in his research finding interest rates have a negative and significant effect on stock prices. However, Riyatno, (2007) found that the interest rate had a negative but not significant effect on systematic risk. 


\section{Exchange Rate}

The exchange rate is the price or exchange rate of the local currency against foreign currencies. The players in the international market are very concerned about the determination of foreign exchange rates (forex) because foreign exchange rates will affect the costs and benefits of "playing" in the trade of goods, services, and securities. Fundamental factors that are thought to have a strong influence on foreign exchange rates are the money supply, relative real income, relative prices, differences in inflation, differences in interest rates, the demand and supply of assets in both countries.

Gustav Cassel, a Swedish economist in 1918, introduced the theory of Purchasing Power Parity (PPP) or in Indonesia known as the purchasing power parity theory, the theory of interest rate parity (IRP), and the International Fisher Parity (IFE) theory. Purchasing Power Parity (PPP) connects foreign exchange rates with commodity prices in local currencies on the international market, i.e., foreign exchange rates will tend to decrease in the same proportion as the rate of a price increase. The decline in the exchange rate because the rate of price increase makes production costs rise, especially in companies that use imported raw materials. As a result, the competitiveness of these companies decreases, because companies must sell their products at higher prices. The three theories, namely PPP, IRP and IFE theories explain the relationship between interest rates and exchange rates. So according to the theory, the difference in interest rates between the two countries will affect changes in exchange rates. So as with interest rates, changes in exchange rates are also in the direction of systematic and opposite or negative risks to stock prices or company values. Research on exchange rates has been carried out, among others by Dedi riyatno, (2007) Research Sudjono, (2002), found the exchange rate (exchange rate) is negatively related to stock prices. Annuar, Salihu, \& Obid, (2014) found that the exchange rate had a negative but not significant effect on the stock beta. While the results of research from Robiatul Auliya et al, (2006) found the exchange rate has a negative and significant effect on stock beta. However, from the results of research by Dedi and Riyatno (2007), the exchange rate found a positive and significant effect on systematic risk.

\section{Capital Expenditure}

Some of the policies taken by the company are investment policies and profit distribution policies or dividend policies. The investment policy will be decided to add new equipment if there is a tendency for economic conditions to improve. One of the company's policies can be seen from the capital expenditure policy regarding funding that must be supported by good asset management, including the management of related resources because this capital expenditure policy is very supportive of success in the financing selection program as well which ultimately can have an impact on increasing the value of the company. The business done by the company in allocating new capital expenditure will be able to see the results after a few years later because this involves long-term investment. It is in line with investment theory, which is intended to expand business opportunities and can only justify if the company's performance is getting better.

The hypothesis developed in this study is as follows:

Ha1: Interest rate has a significant effect on firm value proxied with Tobins'q $\mathrm{Ha}$ 2: Exchange rate has a significant effect on firm value proxied with Tobins'q Ha3: Capital expenditure has a significant effect on firm value proxied with Tobins'q 


\section{Research Method}

The population in this research covers all publicly on manufacturing companies listed in Indonesia Stock Exchange in 2013-2017 and based on the Indonesia Capital Market Institute (TICMI) 2013-2017. All these populations on manufacturing companies must issue the audited annual report completely of 2013-2017 consisting of the statements of financial position, statements of comprehensive income, statements of changes in equity, statements of cash flows, notes to financial statements. The total companies found from purposive sampling are 87 companies. This research was designed using Variance Based SEM (Structural Equation Modeling) or partial least square (SEM-PLS) analysis. The analytical method used to test hypotheses is path analysis. According to Imam Ghozali, (2002), Partial Least Square is a powerful analysis method. PLS is not using many assumptions. Because it focuses more on data and with limited estimation procedures, the model specifications do not significantly affect parameter estimation.

\section{A Measure of the Firm Value}

The dependent variable used in this study was measured using the firm value with measured Tobins'q. Tobin's $Q$ measurement as an indicator of measuring company value has experienced many development Jiraporn, A, (2008) and Chung KH \& Pruit, (1994) use these indicators with the following formula:

$$
(\mathrm{MVE}+\mathrm{TDEBT}) / \mathrm{TA}
$$

$\begin{array}{rrr}\text { firm value } & = & \text { Tobin's } Q \\ \text { market value (closing price) company's stock at the end of the } & \text { MVE } \\ \text { year } & \\ \text { long term debt of book value + short term debt } & \begin{array}{r}\text { TDEBT } \\ \text { asset value's at the end of the year t company i }\end{array} \quad \text { TA }\end{array}$

Companies that use high Tobin's $Q$ or $q>1.00$ indicate that investment opportunities will be better and have high growth potential and also show management that is valued well with the assets under its management whereas the independent variables are the interest rate, exchange rate, and capital expenditure. A real interest rate or free interest rate will use to measure the interest rate. The interest rates of each company use a sensitivity approach, which it is calculated by regenerating the interest rate with stock returns during the study period to get it's Beta (b) value.

\section{A Measure of the Interest Rate}

Interest rates are used as exogenous variables that affect systematic risk and firm value as used in Sudjono's (2002) research with the following formula:

$$
\begin{aligned}
& \text { Interest Rate }: T S B=a+\beta_{r}\left(S R_{i}\right)+e \\
& \text { Which : } \mathrm{SR} \text { i = Stock Return each company } \\
& \mathrm{e}=\text { residual error } \\
& \beta r=\text { Beta interest rate } \\
& \mathrm{a}=\text { intersept }
\end{aligned}
$$




\section{A Measure of the Exchange Rate}

Research for the exchange rate is measured by the real spot exchange rate of the rupiah against the US dollar (\$) and calculated by reverting the change in the real spot exchange rate with stock returns during the study period to obtain it's Beta (b) value. The size of the interest rate used is following research conducted by Iman (2002) as follows:

Exchange Rate : NT $=a+\beta k\left(S_{i}\right)+e$

Which : Sri = Stock Return each company

$$
\begin{aligned}
\beta \mathrm{k} & =\text { Beta interest rate } \\
\mathrm{a} & =\text { intercepet } \\
\mathrm{e} & =\text { residual error }
\end{aligned}
$$

\section{A Measure of the Capital Expenditure}

This study uses capital expenditure indicators as measured by changes in plant, property, and equipment (PPE) values. The formula used is following the research used by Myers, (1984) and Coles J.L, (2004) as follows:

$$
\begin{gathered}
\text { CAPEX }=\text { PPE } /(\mathrm{MV} \text { of Debt }+\mathrm{MV} \text { of Common Stock }) \\
\text { Di mana }: \mathrm{MV}=\text { Market value } \\
\text { PPE }=\text { Property, Plant, and Equipment }
\end{gathered}
$$

\section{Result, Analysis \& Discussion}

Table 4.1 shows the descriptive statistical values for the variables used in this study.

Table 4.1

Description of Statistic Variable

\begin{tabular}{|l|l|r|r|r|r|}
\hline & $\mathrm{N}$ & \multicolumn{1}{|c|}{ Minimum } & Maximum & \multicolumn{1}{|c|}{ Mean } & Std. Deviation \\
\hline Tobin's Q & 435 &, 19 & 13,76 & 2,4190 & 2,16587 \\
Interest rate & 435 & 10,43 & 18,25 & 12,5122 & 1,27786 \\
Exchange rate & 435 & 34,77 & 50,93 & 44,0376 & 5,02789 \\
Capital & 435 &, 00 & 7,88 &, 9949 &, 94601 \\
expenditure & & & & & \\
Valid N (listwise) & 435 & & & & \\
\hline
\end{tabular}

Source: data processing results, 2019

Company value measured by Tobins'q illustrates the manufacturing industry in the 2013-2017 study period, which has a minimum value of $0.19 \%$ and a maximum value of $13.76 \%$. The interest rate used is the SBI interest rate which shows a standard deviation of 1,277 and the average value of the interest rate measured by the SBI interest rate of 12,512 . The exchange rate used in this study is the exchange rate of IDR to USD where the standard deviation of the exchange rate is 5,027, and the average exchange rate change is 44.03 , and the maximum value of the exchange rate variable is 50.93 , and the minimum is at 34.77 . It illustrates that the exchange rate fluctuations are quite high. In this study, the capital expenditure variable 
in manufacturing companies that became the sample of observation has a standard deviation of $94.6 \%$ and an average value of $99.4 \%$.

\section{Testing of Model Measurement (Outer Model)}

Analysis of the outer model or measurement model is a measurement model to connect indicators with latent variables. This measurement model is to assess the validity and reliability of the model through several iterative algorithm processes, measurement model

parameters.

Table 4.2

Loading Factor

\begin{tabular}{|c|c|c|c|c|}
\hline & int & capex & Exc.rate & fm \\
\hline Capex & & 1 & & \\
\hline Int & 1 & & & \\
\hline Exc.rate & & & 1 & \\
\hline Tobin & & & & 1 \\
\hline
\end{tabular}

Source: data processing results, 2019

Table 4.2 loading factor shows the number above the recommended value, which is greater than 0.5. It means that the indicators used in this research model have fulfilled convergent validity. After checking the convergent validity, it is followed by an examination of discriminant validity by looking at the cross-loading value that can see in the results of the data processing algorithm table 4.3

\section{Table 4.3}

Cross Loading

\begin{tabular}{|c|c|c|c|c|}
\hline & int & capex & Exc.rate & fv \\
\hline capex & 0,244475 & 1 & 0,042651 & $-0,94478$ \\
\hline int & 1 & 0,244475 & 0,018626 & $-0,17391$ \\
\hline Exc.rate & 0,018626 & 0,042651 & 1 & $-0,15471$ \\
\hline tobin & $-0,17391$ & $-0,94478$ & $-0,15471$ & 1 \\
\hline
\end{tabular}

Source: data processing results, 2019

An indicator is declared to have a good discriminant validity if it has the highest loading factor to the intended construct compared to loading factor to other constructs. It shows that the indicators have good discriminant validity. 
Table 4.4

\begin{tabular}{|c|c|c|c|c|c|c|}
\hline & AVE & $\begin{array}{c}\text { Composit } \\
\text { e } \\
\text { Reliabilit } \\
\text { y }\end{array}$ & $\begin{array}{c}\text { Cronbac } \\
\text { h's Alpha }\end{array}$ & $\begin{array}{c}\text { Commun } \\
\text { ality }\end{array}$ & $\begin{array}{c}\text { Redundanc } \\
\text { y }\end{array}$ & $\begin{array}{c}\text { redundanc } \\
\text { y }\end{array}$ \\
\hline int & 1 & 1 & 1 & 1 & & \\
\hline capex & 1 & 1 & 1 & 1 & & \\
\hline Exc.rate & 1 & 1 & 1 & 1 & & \\
\hline fv & 1 & 1 & 1 & 1 & $-0,02728$ & $-0,02728$ \\
\hline
\end{tabular}

Source: data processing

results, 2019

In table 4.4 the quality criteria show composite reliability testing, Average Variance Extracted (AVE), and Cronbach's alpha for the interest rate, exchange rate, capital expenditure and firm value constructs showing yield criteria greater than 0.5 , so these constructs are considered to have high reliability and deserves to continue because it meets the requirements.

\section{Testing of Model Structural Structural (Inner Model)}

The feasibility test for the structural model in PLS, namely, smart pls-2 can see from:

a. R Squared to measure the magnitude of the strength of the endogenous variable model

b. Q2 predictive relevance to show inner structural models have predictive relevance or not and measure how well the model and parameters can generate the value of observations The value of $R$ square or determinant coefficient shows how much the independent variables can explain the dependent variable. $R 2$ value at the change value of 0,831 . It means the value of the company can be explained by the exchange rate, interest rates, and capital expenditure of the company, and the rest are other factors outside the research model.

Table 4.5

R Square

\begin{tabular}{|c|c|}
\hline & R Square \\
\hline $\mathbf{f v}$ & 0,830864 \\
\hline
\end{tabular}

Source: data processing results, 2019 
Table 4.6

$Q$ square

\begin{tabular}{|c|c|c|}
\hline & 1-SSE/SSO & criteria \\
\hline capex & 0,708 & $>0,35$ \\
\hline int & 0,557 & $>0,35$ \\
\hline Exch. rate & 0,989 & $>0,35$ \\
\hline fv & 0,350 & $>0,35$ \\
\hline
\end{tabular}

Source: data processing results, 2019

\section{Hypotheses Test}

Hypothesis testing is intended to answer the research questions raised. Following the results of data processing, the research model presented in Figure 4.2 and Figure 4.3 is as follows:

Table 4.7

Path Analysis

\begin{tabular}{|c|c|c|}
\hline Path & Original sample (0) & $\begin{array}{c}\text { T Statistics } \\
\text { (|O/STERR |) }\end{array}$ \\
\hline capex $\boldsymbol{- > \mathbf { f v }}$ & -0.707144 & 10,37533 \\
\hline int $\boldsymbol{- > \mathbf { f v }}$ & 0,065932 & 6,028719 \\
\hline Exch.rate $-\mathbf{f} \mathbf{f v}$ & $-0,019202$ & 6,669502 \\
\hline
\end{tabular}

Source: data processing results, 2019

Based on the results of data processing on table 4.7 for path analysis shows the path analysis (path analysis) seen in the results of the study in Figure 4.2 Algorithm models and Figure 4.3 bootstrapping models.

\section{Picture 4.2}

\section{Model of Algorithm method}

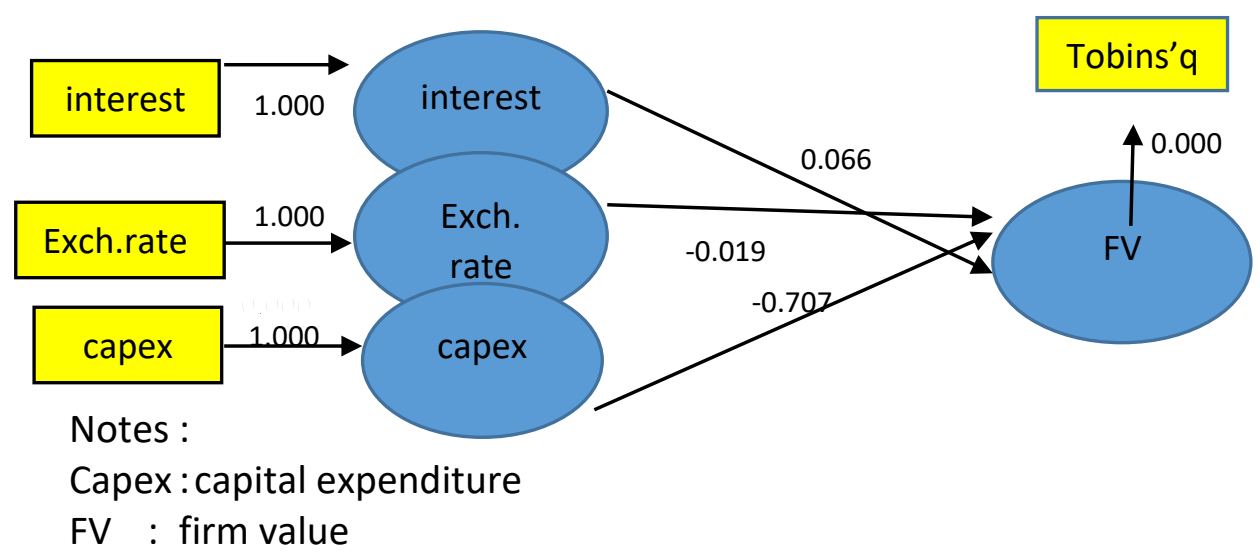


Picture 4.3

Model of Bootstrapping method

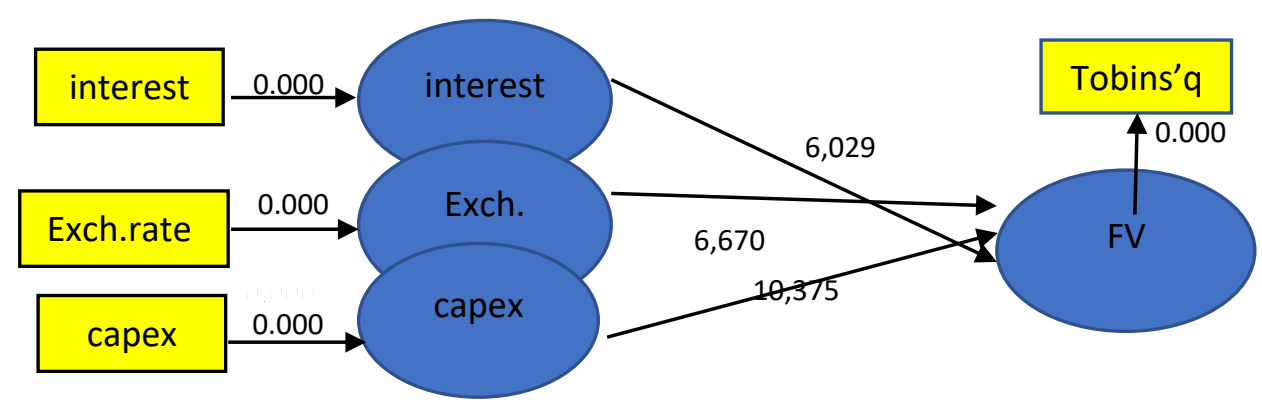

\section{Ha1: Interest Rate has a Significant Positive Effect on Firm Value}

The results of data processing in figures 4.2 and 4.3 show the interest rate statistically positive effect on firm value with a positive parameter coefficient direction of 0.066 with $t$ statistics of 6.029 (> 1.96).

The results of this study are following investment theory that the interest rate is the driver of investment, meaning that market participants view the interest rate as the most important because the interest rate can describe income as well as costs. The interest rate as a barometer of investment profit or return measurement often receives special attention for stock market players. A moderate and stable increase in interest rates will provide certainty for capital market players both in the medium and long term. Short-term investors will pursue high returns when interest rates rise. Investor selling can be dammed and gives a positive signal for investors to buy shares, especially stocks in the manufacturing and property industries. This buying action has an impact on the rise in company stock and increasing the company's value. The results of this study support previous research conducted by Suryanto (1998) and do not support research results from Hamrita \& Trifi, (2011).

\section{Ha2: Exchange Rate has a Significant Negative Effect on Firm Value}

The results of data processing in figures 4.2 and 4.3 show that the exchange rate has a statistically negative effect on the value of the company of -0.019 with a stat of 6.670 (> 1.96) which is indicated by the negative direction of the parameter coefficient of -0.019 . The meaning of the test results is the stock price as an indicator of the value of the company affected by changes in exchange rates. The investor will catch a negative signal over the depreciation of the value of the rupiah against the US dollar. The weakening of the exchange rate or the value of the domestic currency will result in losses on the domestic capital market. Investors are more likely to sell and move to portfolios that bring in more returns, so stock prices decline. Where the decline in the value of the domestic currency will cause investors to be less interested in trading on the stock market in the long run. Besides, in the short term, the weakening of the rupiah against the dollar to a certain extent will tend to provide an attraction for investors to invest in the money market. The results of this study support the research of Robiatul (2006), Javed, (2012). 


\section{Ha3: Capital Expenditure has a Significant Negative Effect on Firm Value}

The results of the research on testing the third hypothesis (Ha3) in figures 4.2 and 4.3 show that company policy measured by the indicator of capital expenditure has a statistically negative effect on the value of the company of -0.707 with at-stat of 10.375 (>1.96). R-square value of 0.831 . It means that the interest rate, exchange rate, and capital expenditure variables can explain the firm value variable of $83.1 \%$ and other variables outside of this research model is the rest. The results of statistical tests show that capital expenditure has a significant negative effect on firm value. The meaning of the test results is capital expenditure (capital expenditure) for plant, property, and equipment (PPE) financing has a significant negative effect on firm value. Investors will analyse the company's motives for investing in capital expenditure. If investment in capital costs will not produce high returns in the future, this policy will be responded to negatively by investors so that this decision is not able to raise share prices, which in turn has an impact on the decline in value of the company. The results of this study do not support and are not following the findings of a study conducted by Coles J.L, (2004) regarding the effect of capital expenditure on Stock Price Volatility. The results of this study are consistent and support the findings of a study conducted by Al Faraoque Tony van Zijl, (2005) regarding the effect of capital expenditure (investment) on Tobin's Q.

\section{Conclusion, Limitation, and Suggestion Conclusion}

The results of this study, in terms of macroeconomic fundamentals, can conclude that there is a positive signal captured by investors over the increase in interest rates. Short-term oriented investors will pursue a return (capital gain) on rising SBI interest rates, so that share prices rise and have an impact on rising corporate value. Rupiah exchange rate has a significant negative effect on company value. The higher the value of the rupiah depreciates the negative impact on stock prices. It shows persistence with the balance of theory portfolio (Marling and \& Emanuelsson, 2012) where the movement of the economy will affect the movement of capital markets and influence the decisions of capital market players. It has an impact on investors who will be more careful in investing if economic conditions are unstable. Company policies proxy by capital expenditure represent investment decisions aimed at increasing and developing investment. In the short term, the effect of capital expenditure cannot produce a return for investors.

To increase the value of the company, the managerial policy is more directed at maintaining price stability if there is a macroeconomy change such as interest rates and exchange rates so that investor confidence does not decline and there is no price shaking on the company's stock price.

\section{Limitation and Suggestions}

In this study, there are limitations only in 5 years with the assumption that the macroeconomic condition is quite stable. In the future, it is necessary to extend the research period and consider aspects of behaviour and culture that can include in the research model. This research suggests that management policies, in this case, directed at anticipating changes in interest rates and maintaining earnings stability so as not to be affected by macroeconomic conditions which are external factors and strengthening the company's fundamentals so that fluctuations in interest changes do not have a major impact on the company. Likewise with 
the exchange rate, management needs to anticipate that the increase in the exchange rate does not have a significant negative impact on the company by maintaining earnings stability to increase investor confidence so as not to switch to the money market or other portfolios. The policy for capital expenditure should be considered the impact of various aspects both short and long term so that management does not burn money, but this policy brings a return for investors.

\section{References}

AnasAl \& Laham. (2013). The effect of financial \& systematic risk on stock returns in the Amman stock exchange. Finance \& Accounting, 4(6).

Annuar, H. A., Salihu, I. A., \& Obid, S. N. S. (2014). Corporate Ownership, Governance and Tax Avoidance: An Interactive Effects. Procedia - Social and Behavioral Sciences. https://doi.org/10.1016/j.sbspro.2014.11.063

Chung, K. H., \& Pruit. (1994). A simple approximation of Tobins'q. Financial Management, 23, 70-74.

Riyatno, D. (2007). Pengaruh suku bunga Sertifikat Bank Indonesia dan Nilai kurs terhadap risiko sistematis di BEl. Keuangan Dan Bisnis, 5(1), 24-40.

Hamrita, M. E., \& Trifi, A. (2011). The relationship between interest rate, exchange rate and stock price: A wavelet analysis. International Journal of Economics and Financial Issues.

Ghozali, I. (2002). Analisis pengaruh kinerja keuangan perusahaan dengan alat ukur EVA, MVA dan ROA terhadap return saham pada perusahaan manufaktur di BEI. AkuntansiBisnisn Dan Manajemen, 9(1), 18-33.

Hartono, J. (2010). Teori Portofolio dan analisis Investasi. Fak Ekonomi Univ. Gajah Mada.

Kasman, S., Vardar, G., \& Tunç, G. (2011). The impact of interest rate and exchange rate volatility on banks' stock returns and volatility: Evidence from Turkey. Economic Modelling. https://doi.org/10.1016/j.econmod.2011.01.015

Marling., and Emanuelsson. (2012). The Markowitz Portfolio Theory. Survey Online Http://Www. Math. Chalmers. Se.

Parlapiano, F., Alexeev, V., \& Dungey, M. (2017). Exchange rate risk exposure and the value of European firms. European Journal of Finance. https://doi.org/10.1080/1351847X.2015.1072570

Sudjono. (2002). Analisis keseimbangan dan hubungan simultan antara variabel ekonomi makro terhadap indeks harga saham di bursa efek jakarta dengan metode VAR (Vector Autoregression) dan ECM (Error Correction Model). Riset Ekonomi Dan Manajemen, 2(3), 81-97.

Villalonga, B. A. R. (2004). How do family ownership, management and controlaffect firm value?, MA 02163(HArvard Business School. The Warton school Univerity of Pennsylvania, PA 19104).

Wijaya, A. M., Widyastuti, T., \& Mappadang, A. (2019). Macroeconomy and Company's Policy on Firm Value: An Interactive Effect on Manufacturing Companies Listed in Idx Period 2013-2017. International Journal of Academic Research in Business and Social Sciences, 9(9), 1046-1060. 